естетичне явище, навчити їх сприймати й осмислювати художній твір як факт мистецтва та через емоційне сприймання словесно-художнього мистецтва усвідомлювати сенс людського життя; увагу учнів слід зосереджувати не лише на подіях твору, а й на тих його компонентах, художніх деталях, які допоможуть виявити виразність, спостерігаючи красу мови, образних висловів, описів, композиційної довершеності тексту; вчити школярів помічати метафоричну форму й переносний зміст, підтекст виучуваного твору; слід однаково уникати як надмірної соціологізації, так і формалізму в роботі над твором; аналіз твору має будуватися 3 урахуванням його жанрово-родової специфіки; уникати шаблонності, урізноманітнювати шляхи, методи і прийоми вивчення художнього твору.

Актуалізація потреби осмисленого й естетичного сприйняття художнього твору зумовлюється взаємозв'язком його змісту і форми, розкрити усю складність якого допоможуть інноваційні технології роботи над текстом - саме в цьому й убачаємо перспективу подальших досліджень.

\title{
Література
}

1. Бровко І. Б. Аналіз літературного твору: [посіб. для вчителів] / І. Б. Бровко, М. Х. Коцюбинська, Г. К. Сидоренко. - Київ : Рад. школа, 1959. - 166 с. 2. Бугайко Т.Ф. Навчання і виховання засобами літератури / Т. Ф. Бугайко, Ф. Ф. Бугайко. - Київ : Рад. школа, 1973. - 176 с. 3. Мазуркевич О. Р. Метод і творчість / О. Р. Мазуркевич. - Київ : Рад. школа, 1973. - 255 с. 4. Марко В. П. І вічна таїна слова: аналіз великого епічного твору : [посіб. для вчителя] / В. П. Марко, Г. Д. Клочек, В. Є. Панченко і ін. - Київ : Рад. школа, 1990. - 205 с. 5. Наукові основи методики літератури: [навч.-метод. посіб.] / за ред. д. п.н, проф., чл.-кор. Н. Й. Волошиної. - Київ : Ленвіт, 2002. - 344 с. 6. Пасічник Є. А. Методика викладання української літератури в середніх навчальних закладах: [навчальний посібник для студентів вищих закладів освіти] / Є. А. Пасічник. - Київ : Ленвіт, 2000. - 384 с. 7. Пультер С. О. Методика викладання української літератури в середній школі / С. О. Пультер, А. М. Лісовський. - Житомир : Полісся, 2000. - 163 с. 8. Рыбникова М. А. Очерки по методике литературного чтения / М. А. Рыбникова. - Москва : Просвещение, 1985. - 288 с. 9. Ситченко А. Л. Навчально-технологічна концепція літературного аналізу / А. Л. Ситченко. - Київ : Ленвіт, 2004. - 305 с. 10. Степанишин Б. І. Викладання української літератури в школі / Б. І. Степанишин. - Київ : Проза, 1995. - 254 с.

\section{ДИСТАНЦІЙНІ ОСВІТНІ КУРСИ: МІЖНАРОДНИЙ ДОСВІД}

Шалацька Г. М. Дистанційні освітні курси: міжнародний досвід.

У статті описано досвід розроблення дистанційного курсу на основі британської навчальної платформи FutureLearn, здійснено аналіз міжнародного досвіду роботи та організації дистанційного освітнього курсу. Зроблено спробу виявити тенденції та шляхи упровадження новітніх технологій у навчанні та підвищенні кваліфікаційного рівня у вітчизняну педагогічну практику.

Ключові слова: дистанційна освіта, курс, комп’ютерні технології, Інтернет, підвищення кваліфікації, навчальна платформа, тьютор.

Шалацкая А. Н. Дистанционные образовательные курсы: международный опыт.

В статье описан опыт разработки дистанционного курса на основе британской 
обучающей платформы FutureLearn, осуществлен анализ международного опыта работы и организации дистанционного образовательного курса. Сделана попытка выявить тенденции и пути внедрения новейших технологий в обучении и повышении квалификационного уровня в отечественную педагогическую практику.

Ключевые слова: дистанционное образование, курс, компьютерные технологии, Интернет, повышение квалификации, обучающая платформа, тьютор.

Shalatska G. M. Distance education courses: the international experience.

The article describes the experience of developing a distance course based on the British training platform FutureLearn. An analysis of international experience and distance education courses is carried out. An attempt to identify tendencies and ways of introduction the new technologies in training and development the qualification level in the domestic pedagogical practice is made.

Key words: distance education, a course, computer technologies, the Internet, professional development, educational platform, the tutor.

Дистанційне навчання (ДН) здійснюється на основі сучасних педагогічних, інформаційних і комп’ютерних технологій та сприяє освітній і професійній підготовці майбутніх спеціалістів. Мільйони користувачів задовольняють свої освітньо-інформаційні потреби, використовуючи Інтернет. Дистанційні освітні курси (ДОК) набувають поширення у зв’язку із зростанням інформатизації суспільства, необхідністю постійного підвищення професійної кваліфікації спеціалістів, потребою в отриманні додаткових спеціальностей, наданні творчого складника навчанню, посиленні ролі самоосвіти, що зумовлено вимогами до якості, доступності та зручності навчання. Актуальність дослідження полягає в тому, що на сучасному етапі розвитку педагогічної науки ще не проведено грунтовний аналіз діяльності конкретних зарубіжних навчальних закладів, які уже запровадили ДОК, досвід яких можна було б використати. У наш час бракує необхідної навчальної літератури для підготовки випускників ВНЗ, які могли б продовжувати ДН в освітніх закладах, проходити курси підвищення кваліфікації або отримувати другу спеціальність без відриву від виробництва.

Метою дослідження $є$ аналіз міжнародного досвіду роботи та організації ДОК, виявлення тенденцій та шляхів упровадження їх у вітчизняну педагогічну практику. Відповідно до зазначеної мети ми поставили такі завдання: окреслити тематику міжнародних ДОК; проаналізувати структуру організаційної моделі ДОК; визначити перспективи упровадження ДОК в систему вищої освіти України.

У своїх працях В. Биков, Ю. Дорошенко, М. Жалдак, А. Хуторський торкались проблем та напрямів досліджень ДН. Підходи до реалізації та організаційно-педагогічні основи дистанційної освіти у своїх працях розглядали Г. Атанов, С. Гахович, Р. Гуревич, П. Дмитренко, В. Олійник, Ю. Пасічник, А. Солодовник, П. Таланчук, В. Шейко та ін. Перспективи ДН у вищих навчальних закладах України та за кордоном описуються у роботах Г. Козлакова, К. Корсак та П. Стефаненко. ДН іноземних мов та розробленню і використанню мультимедійних технологій присвячені наукові праці В. Дейнеко, В. Жулкевської, Н. Муліна, В. Редько, В. Свиридюк, П. Сердюкова, О. Сороки, Б. Шуневича та інших.

Перш ніж перейти до розгляду досліджуваної проблеми, слід надати визначення ключовому поняттю, у розумінні якого ми спирались на визначення А. Хуторського, який 
уважав, що ДН - це навчання за допомогою засобів телекомунікацій, при якому віддалені один від одного суб'єкти навчання здійснюють навчальний процес, який супроводжується створенням навчальної продукції [4]. На думку ж Б. Шуневича, особливість ДН полягає у «створенні можливостей організації сучасного навчального процесу на рівні денного з усіма атрибутами», щоб студенти мали можливість «отримати у разі необхідності пояснення, роз'яснення викладачем навчального матеріалу», могли здійснити «спілкування 3 викладачем i студентів між собою протягом усього періоду навчання», а також уможливлювали «проведення обговорень, проміжного і підсумкового тестів, виконання спільних завдань, у тому числі дослідницького і творчого характеру тощо». Усі ці чинники «визначають ДН як навчальний процес (можливість організації активної пізнавальної діяльності кожного студента; забезпечення ефективного зворотного зв'язку, інтерактивності; індивідуалізації і диференціації процесу навчання; формування стійкої мотивації навчальнопізнавальної діяльності)» [7, с. 4].

Організацію дистанційної освіти забезпечують електронні освітні ресурси, помітне місце серед яких належить ДОК. С. Гахович зазначає, що ДОК - це «інформаційна система, яка $\epsilon$ достатньою для навчання окремим навчальним дисциплінам за допомогою опосередкованої взаємодії віддалених один від одного учасників навчального процесу у спеціалізованому середовищі, яке функціонує на базі сучасних психолого-педагогічних та інформаційно-комунікаційних технологій» [1, с. 198]. На думку дослідника, «електронний курс дистанційного навчання має бути побудований так, щоб максимально забезпечити заміну викладацького контролю самоконтролем, дати можливість студентам розробити власну траєкторію самоосвіти. Тому всі матеріали повинні містити докладний опис раціональних прийомів усіх видів діяльності, критеріїв правильності рішень, рекомендації з ефективного використання консультацій» [1, с. 201]. Однак С. Гахович також уважає, що «електронний навчальний курс не зможе повністю замінити викладача, оскільки живе спілкування не зможе замінити жодна комп'ютерна технологія. Основною його метою $є$ створення сучасних комфортних умов для формування наукового світогляду тих, хто навчається, у процесі вивчення будь-якої дисципліни» [1, с. 203]. 3 нашого погляду, це дещо зумовлює стандартизацію навчального процесу, а новітні технології не зменшують ролі викладача, а покликані розширити можливості і викладача, і студента, а також того, хто хоче поновити свої знання та підвищити кваліфікацію.

На сучасному етапі розвитку дистанційної освіти розпочинається активне впровадження ДОК та залучення мільйонної аудиторії користувачів до навчання в Інтернеті. 3 цього приводу Б. Шуневич зауважував, що «в останні роки постійно збільшується кількість дистанційних курсів у ВНЗ України. Найбільшою кількістю ДК представлено групи дисциплін з менеджменту, маркетингу, фінансів, обліку й аудиту, а також банківської справи, які разом 3 дистанційними курсами 3 загальноекономічних, гуманітарних i фундаментальних дисциплін є основою для підготовки програм навчання з метою здобуття другої вищої освіти в комерційних і технічних ВНЗ. За останні 5 років відбулося об’єднання низки навчальних закладів та інших організацій у спільні центри». На його думку, «лише за умови об’єднання зусиль таких центрів ДН можна буде швидко досягти світових стандартів у розробці нормативно-правової бази, підготовці кваліфікованих розробників дистанційних курсів, викладачів-консультантів (тьюторів), спільних навчальних матеріалів тощо. На сучасному етапі розвитку центри пропагують упровадження новітніх технологій у навчальний процес, розробляють дистанційні курси, забезпечують підготовку i перепідготовку організаторів, розробників дистанційних курсів, тьюторів, дизайнерів, 
методистів, які могли би активно впроваджувати нову форму навчання у своїх навчальних закладах» [7, с. 16]. На нашу думку, такий підхід підніме процес навчання в Україні на новий вищий рівень, гуманізує та демократизує його, дасть можливість застосовувати міжнародний досвід.

У наш час відбувається розроблення методичної бази ДОК, розглядаються способи організації дистанційних занять, шляхи технічного забезпечення навчального процесу 3 упровадження дистанційної освіти. У своїй статті А. Солодовник виокремлює два типи ДОК: 1) дистанційні курси для самостійного навчання; 2) дистанційні курси групового вивчення. Перший тип ДК безкоштовно забезпечує студента комплектом навчальних матеріалів, студент «виконує всі вказівки, самостійно перевіряє рівень своїх знань, опрацьовує матеріали з додаткових ресурсів мережі Інтернет та ін. Недоліком таких курсів $є$ те, що по закінченні навчання студент не отримує сертифікат про якість знань» [6, с. 148]. Другий тип ДК передбачає оплату за навчання, відзначається «активним обміном інформації між викладачем (тьютором) та студентами... Такий курс, як правило, входить до системи підготовки фахівця певної кваліфікації» [6, с. 149]. У ньому, як указує дослідник, установлено також контрольні терміни навчання.

Популяризації ДОК сприяє проведення занять у режимі відео конференцій, які набувають все більшого поширення в навчанні та науковому спілкуванні. Для організації і впровадження дистанційного спілкування використовують наявне в Інтернеті програмне забезпечення, до якого є вільний доступ. Під час ДН зростає роль студента у процесі здобуття знань за наявності відповідної мотивації, а викладач лише допомагає йому організувати навчальний процес. Завдання викладача полягає в тому, щоб забезпечити творче й активне оволодіння студентами знаннями, набуття вмінь і навичок у вибраній ними галузі. Запорукою ефективності ДОК є встановлення якісного зворотного зв’язку між викладачем і студентом. Результативність навчання залежить від цілеспрямованості, відповідальності та чесності студента. Поява ДОК за професійним спрямуванням стимулює бажання вчитися, розширює зону індивідуальної активності кожного студента, збільшує швидкість подачі навчального матеріалу в рамках однієї теми. ДОК сприяють подоланню кризи освіти, спонукають до постійного творчого вдосконалення та розвитку людини протягом усього життя. ДОК характеризуються потоком великої інформації, для роботи 3 якою необхідні вміння аналізувати та систематизувати матеріал. ДОК передбачають, щоб студент мав сильну особистісну мотивацію, володів умінням навчатися самостійно без постійного підштовхування з боку викладача. У розпорядженні студента необмежений вибір навчальних закладів, що не залежить від місця його перебування та віддаленості від наукових осередків.

Навчальна британська платформа FutureLearn, маючи великий міжнародний досвід роботи, пропонує різноманітні курси від провідних зарубіжних університетів. Це приватна компанія, яка повністю належить Британському Відкритому університету. За твердженням Т. Пилаєвої, «зараз Відкритий університет - це найбільший університет Великої Британії. 3 моменту заснування більш ніж три мільйони студентів пройшли навчання за програмами Відкритого університету. Відкритий університет, адміністративна частина якого знаходиться у графстві Бекінгемшир, має регіональні офіси в тринадцяти регіонах Великої Британії, а за межами Європейського Союзу працює через мережу освітніх партнерів, які забезпечують навчальний процес за програмами Відкритого університету в більш ніж 50 країнах. Завдяки дистанційним методикам, що використовуються, навчання за програмою Відкритого університету стало доступним для студентів Європи та Азії» [3, с. 115]. Крім того, партнерами FutureLearn $є 72$ освітні заклади по всьому світі. Свою роботу курси від 
FutureLearn розпочали у вересні 2013 року. Нині до навчання на дистанційних курсах цієї організації долучилось більше ніж 2 мільйони студентів [5].

Навчальна платформа FutureLearn створена за допомогою залучення експертних знань, отриманих від Відкритого університету, та грунтується на підході Massive-scale social learning (крупний масштаб соціальної освіти), який потребує роботи з великою кількістю студентів. Такі курси найбільш підходять тим людям, які пов’язали своє життя з певною сферою діяльності і хочуть розширити чи поглибити свої знання, підвищити кваліфікацію, покращити рівень володіння іноземною мовою.

Тематика курсів постійно оновлюється, кожен курс відрізняється тривалістю навчання. Більшість з курсів тривають від 6 до 10 тижнів, найкоротший курс триває від 2 до 3 тижнів. Усі запропоновані дистанційні курси групуються за темами: «Бізнес та менеджмент», «Креативна творчість та ЗМІ», «Здоров’я та психологія», «Історія», «Мова та культура», «Закон», «Література», «Природа та оточуючий світ», «Інтернет та цифрові технології», «Політика та сучасний світ», «Наука, математика та технології». Онлайн-курси, засновані на навчальних матеріалах Британської Ради (British Council), допомагають покращити навички викладання англійської мови, спрямовані на постійне підвищення кваліфікації для тих, хто викладає англійську мову як іноземну. Кожен, хто бажає навчатися на ДК, має пройти процес реєстрації для отримання доступу до навчальних матеріалів, координатів викладача, можливість відслідковувати всі його повідомлення. Спілкування 3 тьютором відбувається через коментарі до навчального матеріалу, через сервіси Facebook та Twitter. Навчальна інформація подається в різних форматах: текстовому, відео-, таблицях, презентаціях, схемах. До кожного заняття є свій тематичний чат, де всі слухачі курсу обмінюються повідомленнями в реальному часі, своїми враженнями від отриманої інформації та відповідають на питання, поставлені викладачем у кінці заняття. Наявність такого чату забезпечує спілкування між колегами-студентами з метою обміну досвідом. Усі повідомлення викладача, його коментарі до відповідей кожного зі студентів доступні всім, хто навчається на цих дистанційних курсах.

Основна маса студентів, які навчаються на ДОК - це люди після 25 років, які вже здобули професію, працюють, але хочуть підвищити свою кваліфікацію чи отримати додаткову спеціальність, прагнучи гармонійно поєднати навчання і повсякденне життя. Час, інтенсивність та тривалість занять вибирає той, хто навчається. Студент може отримати доступ до навчальної інформації через мобільний телефон, планшет чи нетбук, а значить це не обмежує його матеріальні та технічні можливості. Слід відзначити, що всі ДК, представлені компанією FutureLearn, спроектовані відповідно до принципу ефективного навчання через дискусії з однокурсниками та розповіді провідних спеціалістів з певної галузі знань, які доповнюються статтями, таблицями, схемами, переліком електронних ресурсів для отримання додаткової інформації.

Розпочавши навчання на ДК, кожен має можливість контролювати процес навчання. У розпорядженні студента $є$ орієнтовний розклад занять, термін навчання, дати початку та кінця вивчення теми, час онлайн-зустрічі з викладачем. Кожен навчальний курс поділено на тижні, кожен тиждень має свою описову назву, тому студент завжди знає, що його чекає, він може вільно переміщатись між ними та переглядати зміст як минулих, так і майбутніх занять. Сторінка під назвою «список задач» забезпечує навігацію по всьому обраному курсу, синім кольором позначено пройдений матеріал, а фіолетовим - новий матеріал. Переглянувши відео, прочитавши статті та відповівши на запитання, студент ставить відмітку про виконання і переходить до наступної теми навчання, але завжди залишається 
можливість повернутись до будь-якої теми і переглянути матеріал ще раз. Залучення до дискусії з іншими учасниками курсу надає можливість узагальнити отримані знання та побачити, яка саме з тем, що вивчаються, викликала найбільше зіткнення різних думок. Більшість завдань містять короткі опитування для перевірки якості засвоєння матеріалу. За відповіді студенти оцінки не отримують, відбувається лише зворотний зв'язок та надаються певні підказки. Викладач здійснює аналіз відповідей студентів, робить узагальнення і підбиває підсумки тижневої роботи у своєму відеозверненні. У кінці навчального курсу подається тест для перевірки отриманих знань, де кількість правильних відповідей лімітована трьома спробами, і після його проходження уже ставиться оцінка. Для отримання можливості придбати сертифікат, який засвідчить проходження студентом курсу, потрібно пройти основні етапи навчання та скласти всі тести. Лише засвоївши не менше 50 відсотків матеріалу, позитивно оціненого викладачем, студент отримує сертифікат.

Зарубіжний досвід організації дистанційної освіти стимулює упровадження світових інновацій у вітчизняну систему педагогічної освіти. ДОК забезпечують масову підготовку та перепідготовку спеціалістів різного профілю 3 використанням як традиційних, так i інноваційних методів, засобів i форм навчання, які грунтуються на комп’ютерних технологіях. У сучасних умовах виникає необхідність модернізації свого освітньопрофесійного рівня шляхом підвищення кваліфікації, тому важливим завданням є створення та реалізація умов для забезпечення особистісного і професійного розвитку спеціалістів. На думку В. Олійника, особливість ДК 3 використанням інтернет-технологій визначає перспективність їх упровадження. Вони здатні забезпечити рівний доступ до якісної освіти, зручність навчання, економічність фінансів та свободу вибору [2].

Б. Шуневич уважає, що основними причинами незадовільного впровадження дистанційної освіти в Україні $є$ «висока вартість комп’ютерної техніки, програмного забезпечення і доступу до Інтернету, низька пропускна спроможність ліній зв'язку, а також відсутність відповідної нормативно-правової бази, організаційного, науково-методичного, інформаційно-телекомунікаційного, матеріально-технічного, кадрового, економічного та фінансового забезпечення системи дистанційного навчання та інших складників організації ДН..., недовірливе ставлення студентів і викладачів до цієї форми навчання, їх непідготовленість до роботи із сучасним апаратним і програмним забезпеченням» [7, с. 23]. Сертифікати, отримані викладачами у ході навчання на ДК в Україні, як зазначає дослідник, «не мають юридичної сили при влаштуванні на роботу і $є$ лише підтвердженням того, що вони навчалися на таких курсах» [7, с. 29]. Такий підхід до ДК навчання в Україні дещо зменшує коефіцієнт корисної дії всієї дистанційної освіти та відмежовує її від міжнародного досвіду. У перспективі планується дослідити також інші педагогічні аспекти цього складного явища та можливості впровадження дистанційних освітніх курсів у ВНЗ України.

\section{Література}

1. Гахович С. В. Методичні рекомендації для створення курсів дистанційного навчання / С. В. Гахович // Збірник наукових праць Військового інституту Київського національного університету імені Тараса Шевченка. - 2014. - Вип. 47. - С. 197-204. - Режим доступу: http://nbuv.gov.ua/j-pdf/Znpviknu_2014_47_32.pdf. 2. Олійник В. В. Організаційнопедагогічні основи дистанційної освіти і навчання: Організаційно-педагогічне дослідження / В. В. Олійник. - Київ : ЦІППО, 2001. - 47 с. 3. Пилаєва Т. В. Початковий етап розвитку дистанційної освіти у Великій Британії / Т. В. Пилаєва // Духовність особистості. - 2012. Вип. 2. - С. 108-117. 4. Практикум по дидактике и современным методикам обучения / А. В. Хуторской. - Санкт-Петербург : Питер, 2004. - 541 с. 5. Режим доступу : https:// 
www.futurelearn.com/about. 6. Солодовник А. О. Інформаційний супровід дистанційного курсу «Теорія розв’язування винахідницьких задач» / $\quad$ А. О. Солодовник, $\quad$ В. Д. Шарко // Інформаційні технології в освіті. - 2011. - Вип. 9. - С. 146-157. 7. Шуневич Б. І. Розвиток дистанційного навчання у вищій школі країн Європи та Північної Америки: автореф. дис. на здобуття наук. ступеня доктора пед. наук : спец. 13.00.01 - «Загальна педагогіка та історія педагогіки» / Шуневич Б. І. - Київ, 2008. - 38 с. 